\title{
Atmospheric transport of persistent semi-volatile organic chemicals to the Arctic and cold condensation in the mid-troposphere - Part 1: 2-D modeling in mean atmosphere
}

\author{
J. Ma \\ Air Quality Research Division, Environment Canada, 4905 Dufferin Street, Toronto, Ontario M3H 5T4, Canada \\ Received: 26 August 2009 - Published in Atmos. Chem. Phys. Discuss.: 12 January 2010 \\ Revised: 22 July 2010 - Accepted: 26 July 2010 - Published: 9 August 2010
}

\begin{abstract}
In the first part of this study for revisiting the cold condensation effect on global distribution of semivolatile organic chemicals (SVOCs), the atmospheric transport of SVOCs to the Arctic in the mid-troposphere in a mean meridional atmospheric circulation over the Northern Hemisphere was simulated by a two-dimensional (2-D) atmospheric transport model. Results show that under the mean meridional atmospheric circulation the long-range atmospheric transport of SVOCs from warm latitudes to the Arctic occurs primarily in the mid-troposphere. Although major sources are in low and mid-latitude soils, the modeled air concentration of SVOCs in the mid-troposphere is of the same order as or higher than that near the surface, demonstrating that the mid-troposphere is an important pathway and reservoir of SVOCs. The cold condensation of the chemicals is also likely to take place in the mid-troposphere over a source region of SVOCs in warm low latitudes through interacting with clouds. We demonstrate that the temperature dependent vapour pressure and atmospheric degradation rate of SVOCs exhibit similarities between lower atmosphere over the Arctic and the mid-troposphere over a tropical region. Frequent occurrence of atmospheric ascending motion and convection over warm latitudes carry the chemicals to a higher altitude where some of these chemicals may partition onto solid or aqueous phase through interaction with atmospheric aerosols, cloud water droplets and ice particles, and become more persistent at lower temperatures. Stronger winds in the mid-troposphere then convey solid and aqueous phase chemicals to the Arctic where they sink by large-scale descending motion and wet deposition. Using calculated water droplet-air partitioning coefficient of several persistent or-
\end{abstract}

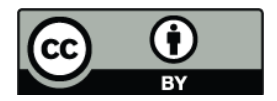

Correspondence to: J. Ma

(jianmin.ma@ec.gc.ca) ganic semi-volatile chemicals under a mean air temperature profile from the equator to the North Pole we propose that clouds are likely important sorbing media for SVOCs and pathway of the cold condensation effect and poleward atmospheric transport. The role of deposition and atmospheric descending motion in the cold condensation effect over the Arctic is also discussed.

\section{Introduction}

Enrichment of semi-volatile organic pollutants (SVOCs) at higher latitudes and the Arctic have been stimulating extensive studies in the scientific community since the 1980s (Goldberg, 1975; Ottar, 1981; Rahn and Heidam, 1981; Macdonald et al., 2000; Meijer et al., 2003). The ability of a specific chemical to travel from its source to the Arctic and deposit there depends on the physical-chemical properties of the chemical itself, the pathway it takes to move towards the north, and environment and climate pattern along that path. A widely cited hypothesis that explains the enrichment of solid and liquid phases SVOCs in the cold environments is the global distillation effect (Mackay and Wania, 1995). Other terminologies have been also used to describe the complement of the global distillation process, e.g., "cold condensation" (Ottar, 1981), and "cold trapping" (Rahn and Heidam, 1981). Because SVOCs cannot undertake a "condensation" process under cold temperatures, Wania and Westgate (2008) suggest that this process should be more properly termed "cold trapping". The northward transport and accumulation of SVOCs have been explored in a number of studies examining latitudinal trends in concentration and composition of SVOCs (Wania and Mackay, 1993, 1996; Mackay and Wania, 1995; Macdonald et al., 2000; Meijer et al., 2003;

Published by Copernicus Publications on behalf of the European Geosciences Union. 
Semeena and Lammel, 2005). This notion of contaminant transport has been further developed into the concept of latitudinal fractionation, a process in which certain components of the original mixture of substances are preferentially transported and accumulated in environmental media at higher latitudes, thereby resulting in a change in the mixture's composition (Meijer et al., 2002).

There are various definitions on the global distillation/cold condensation effect and similar processes. One of the explanations, adopted by a document of the UNEP (United Nation Environment Programme), states that: "There is a systematic transfer of these chemicals from warmer to colder areas through the process of global distillation. The pollutants evaporate from soils in warm areas such as the tropics, are transported as vapour around the globe, and condense over cold areas as toxic snow or rain" (http://earthwatch.unep. net/toxicchem/pops.php).

For those persistent SVOCs subject to long-range transport (LRT), a key point is: in what manner will these chemicals be migrated to the polar region? The atmosphere is a three dimensional mobile medium, so is the atmospheric motion. From a meteorological perspective, the mean meridional atmospheric circulations and the surface friction do not favour the LRT to the Arctic at a lower atmospheric level or within the atmospheric boundary-layer. The atmospheric transport of a chemical occurs most efficiently at a higher elevation rather than near the surface where strong surface friction and turbulence quickly disperse the air concentration of the chemical, as demonstrated by numerical investigations of episodic LRT event of toxaphene and lindane (Ma et al., 2005; Zhang et al., 2008).

If poleward atmospheric transport of SVOCs took place in the mid-troposphere, a subsequent question is: does cold trapping effect also occur in the mid-troposphere? Abundant field measurements have demonstrated increase of SVOCs over high mountains associated with declining of air temperature, designated as mountain cold trapping (Calamari et al., 1991; Blais et al., 1998; van Drooge et al., 2004; Wania and Westgate, 2008; MONARPOP, 2009). While SVOCs migrate at a higher atmospheric level, one may expect that the cold trapping process can also occur at the higher atmosphere altitudes in a similar manner as that in the Arctic and high mountains. However, under the lower air temperature regime in the Arctic a chemical may adsorb or partition onto soil, vegetation, water, aerosols, snow and ice (Wania and Mackay 1993). The major pathways for the cold trapping in the mid-troposphere, however, differ somewhat from the Arctic or mountain cold trapping because at a higher atmosphere there do not exist that many sorbing media as in the Arctic and at high mountains.

The objectives of the present study are (1) to examine major atmospheric pathways of poleward transport of SVOCs under a mean meridional atmospheric circulation, and (2) to examine the cold trapping of SVOCs in the mid-troposphere over the warm latitudes. In the first part of the study a two- dimensional (2-D) atmospheric transport equation model was employed to simulate the long-range atmospheric transport of SVOCs from tropical latitudes to the Arctic and the cold condensation effect under a mean meridional atmospheric circulation, and to examine conceptually the UNEP's statements on global distillation. In the accompany paper (Zhang et al., 2010) two 3-D atmospheric transport models for SVOCs were used to extend the 2-D atmospheric modeling to 3-D atmospheric simulations for episodic poleward atmospheric transport of SVOCs in the mid-troposphere. Given that $\alpha$ - and $\gamma$-hexachlorocyclohexane (HCHs) are the most abundant SVOCs in the Arctic atmosphere and surface waters and subject to LRT due to their strong persistence in environments (Macdonald et al., 2000), as demonstrated by extensive modeling studies (Koziol and Pudykiewicz, 2001; Ma et al., 2003; Hansen et al., 2004; Semeena and Lammel, 2003, 2005; Zhang et al., 2008, Tian et al., 2009), they were selected in most modeling investigations in the present study. Although some SVOCs in the Northern Hemispheric oceans also show latitudinal increases towards the Arctic (Wania and Mackay, 1996; Stroebe, et al., 2004), this study will focus on the atmospheric transport in the context of the UNEP's statements on global distillation. Although the global distillation / cold condensation terminologies have been mostly used in the UNEP's statements and many other studies, in the present study "cold trapping" will be used wherever possible.

\section{Background mean meridional atmospheric circulation for poleward atmospheric transport}

Figure 1 shows a mean air temperature profile over the Northern Hemisphere from 1950 through 1980. Using the mean air temperatures collected from the NCEP (National Centers for Environmental Prediction) reanalysis (Kalney, et al., 1996), as shown in Fig. 1, we have calculated temperature dependent degradation rate constant in the air (Brubaker and Hites, 1998) and vapour pressure of $\gamma-\mathrm{HCH}$ (or lindane), a persistent semi-volatile organochlorine insecticide. The results are also presented in Fig. 1. The highest air temperature can be observed at relatively lower atmospheric levels and in tropical and sub-tropical regions between $10^{\circ}-30^{\circ} \mathrm{N}$. The air temperature declines towards higher latitudes and the polar region, and higher atmospheric levels. Accordingly, the temperature dependent degradation rate constant (white solid line) and vapour pressure (black dashed line) exhibit the similar decreasing pattern. For instance, it can be seen that the degradation rate of lindane at $500-\mathrm{hPa}(\sim 5500 \mathrm{~m}$ height $)$ over the tropical latitudes is identical to that near the surface to the north of $70^{\circ} \mathrm{N}$, and the vapour pressure at a value of $0.001 \mathrm{~Pa}$ near the surface of $80^{\circ} \mathrm{N}$ can be also found below $400-\mathrm{hPa}$ ( $\sim 7000 \mathrm{~m}$ height) over the tropical latitudes. The vapour pressure within the range of $0.001-0.01 \mathrm{~Pa}$ lies between 650 $400 \mathrm{hPa}$, about 3600-6000 $\mathrm{m}$ height above sea level, and locates in the mid-troposphere to the south of $30^{\circ} \mathrm{N}$. The same 


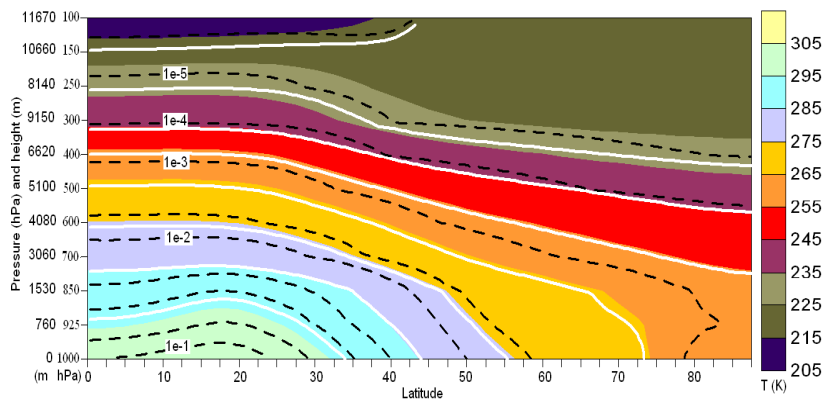

Fig. 1. Vertical profile of zonally averaged air temperature (colorcontoured) over Eurasia $\left(0-140^{\circ} \mathrm{E}\right)$ from 1950 through 1980. White solid line indicates the temperature-dependent first order degradation rate of $\gamma-\mathrm{HCH}$ and black dashed line stands for vapour pressure of $\gamma-\mathrm{HCH}(\log P=11.98-3905 / \mathrm{T}$, Xiao, et al., 2004). The change in degradation rate constant is determined by temperature fluctuation and $\mathrm{OH}$ radical concentration, defined as $K_{e}=K_{v} \cdot[\mathrm{OH}] \cdot 1.0 \times 10^{6} \cdot \exp \left[(\Delta \mathrm{E} / \mathrm{R}) \cdot\left(1 / T_{v}-1 / T_{e}\right)\right]$, where $K_{e}$ is the modified reaction (degradation) rate, $K_{v}$ is the reference degradation rate constant $\left(\mathrm{m}^{3} \mathrm{~mol}^{-1} \mathrm{~s}^{-1}\right), O H$ is the concentration of hydroxyl radicals in air $\left(=17 \times 10^{5}\right.$ molecules $\mathrm{cm}^{-3}$ averaged over the Northern Hemisphere using values collected by Toose et al. (2004) which is higher than Spivakovsky et al's value $\left(11 \times 10^{5}\right.$ molecules $\left.\mathrm{cm}^{-3}, 2000\right), \Delta \mathrm{E}$ is the activation energy ( $\mathrm{J} \mathrm{mol}^{-1}$, Table 1$), R$ is the gas law constant $\left(\mathrm{J} \mathrm{mol}^{-1} \mathrm{~K}^{-1}\right)$, and $T_{e}$ and $T_{v}$ are ambient and reference temperature, respectively. On $\mathrm{y}$-axis the vertical height $(\mathrm{m})$ corresponds to pressures, calculated using the constant air density $\rho$ and the hydrostatic relationship $d p / d z=-\rho g$, where $g$ is the acceleration due to gravity.

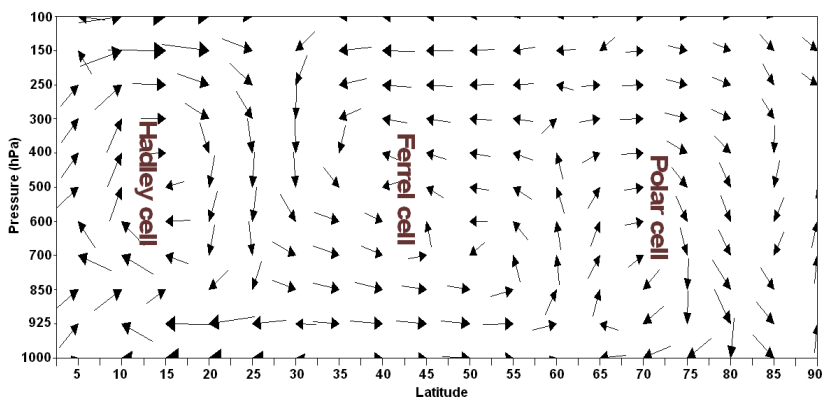

Fig. 2. Vertical profile of vector winds, derived from zonally averaged meridional wind $\left(\mathrm{m} \mathrm{s}^{-1}\right)$ and vertical velocity $\left(\mathrm{m} \mathrm{s}^{-1}\right)$, spanning from equator to North Pole, averaged over springs from 1950 through 1980 and over the Northern Hemisphere. In presentation, vertical velocity has been multiplied by 100 .

range of the vapour pressure can be seen near the surface between $60^{\circ}-80^{\circ} \mathrm{N}$.

Figure 2 illustrates a vertical cross-section of the vector winds derived from mean meridional wind $\left(\mathrm{m} \mathrm{s}^{-1}\right)$ and vertical velocity $\left(\mathrm{m} \mathrm{s}^{-1}\right)$ from the equator to the North Pole, averaged over springs from 1950 through 1980 and over the Northern Hemisphere, using the data from the NCEP reanalysis. It shows three well-known meridional atmospheric cells, namely, the Hadley cell, Ferrell cell, and Polar cell, spanning from the equator to the North Pole (Holton, 2004). Based on the classic Hadley cell theory (Holton, 2004), warm air rises near the equator and the tropics, cools as it travels poleward at high altitudes, sinks as cold air, and warms as it travels equator-ward. This renders the poleward atmospheric transport from lower latitudes unlikely to occur at the lower level of the mean meridional atmospheric circulations.

\section{Model description and methods}

To address the cold trapping effect under the mean meridional atmospheric circulation (Figs. 1 and 2) and in the context of the UNEP's statements, we seek analytical and numerical solutions to a two-dimensional atmospheric transport (dispersion) equation for a SVOC:

$\frac{\partial c}{\partial t}+\bar{v} \frac{\partial c}{\partial y}+\bar{w} \frac{\partial c}{\partial z}=\frac{\partial}{\partial z}\left(K_{c} \frac{\partial c}{\partial z}\right)-\Gamma c$

where $c$ is the air concentration $\left(\mathrm{pg} \mathrm{m}^{-3}\right), z(\mathrm{~m})$ is the vertical coordinate in the atmosphere. In Eq. (1) we have assumed that the $y$-axis is orientated in the direction of the mean meridional wind $\bar{v}$ and $\bar{u}=0\left(\mathrm{~m} \mathrm{~s}^{-1}\right)$ and in this direction the horizontal advection dominates the transport of an air pollutant. $\bar{w}$ is the mean vertical velocity $\left(\mathrm{m} \mathrm{s}^{-1}\right) . K_{c}$ $\left(\mathrm{m}^{2} \mathrm{~s}^{-1}\right)$ in Eq. (1) is the eddy diffusivity for air concentration. $\Gamma\left(\mathrm{s}^{-1}\right)$ is an overall decay rate constant accounting for the degradation rate constant in air and the air-to-surface mass transfer (Bennett et al., 1999; Beyer et al., 2000).

Equation (1) is solved numerically and analytically. For steady state $(\partial c / \partial t=0)$ of Eq. (1), following Bennett et al. (1999) and Beyer et al. (2000), the overall decay rate constant $\Gamma$ can be defined as

$\Gamma=\eta_{A}+F_{S} K_{A S} / z$

where $\eta_{A}\left(\mathrm{~s}^{-1}\right)$ is the first-order degradation rate constant in air, $K_{A S}\left(\mathrm{~m} \mathrm{~s}^{-1}\right)$ is the mass transfer coefficient from air to soil, $F_{s}$ is expressed as the ratio of the net downward flux to the gross downward flux:

$F_{S}=\frac{\eta_{S}}{\eta_{S}+K_{S A} / z_{S}}$

where $\eta_{s}\left(\mathrm{~s}^{-1}\right)$ is the first-order degradation rate constant in soil, $K_{S A}\left(\mathrm{~m} \mathrm{~s}^{-1}\right)$ is the mass transfer coefficient from soil to air, and $z_{s}$ is the soil depth. Following Beyer et al. (2000), equation (2) can be expanded to include other air/surface exchange processes (e.g., water surface) by expressing $\Gamma$ as the air compartment in contact with several media $j$ with summations over all media:

$\Gamma=\eta_{A}+\sum F_{j} K_{j} / z$

where $K_{j}$ is the mass transfer coefficient from air to medium $j$ and $F_{j}$ is the fraction of SVOCs transported from air to 
any underlying medium $j$ and can be expressed as the form of Eq. (3) but replacing the first-order degradation rate constant in soil and the soil-air mass transfer coefficient by their expressions in other media.

For steady state solution, the eddy diffusivity in the neutral atmosphere is defined by (Garratt, 1992; Nieuwstadt, 1983)

$K_{c}=\kappa u_{*} z(1-z / h)$,

where $\kappa$ is the von Karman constant $(=0.4), u_{*}\left(\mathrm{~m} \mathrm{~s}^{-1}\right)$ is the friction velocity. Usually, $K_{c}$ is designated and used in the planetary boundary layer (PBL). Because the influence of the atmospheric turbulence induced by underlying surfaces on the vertical transfer of a chemical is well beyond the PBL up to $10 \mathrm{~km}$ (Nieuwstadt, 1983; Strand and Hov, 1996), following these literatures we have extended $K_{c}$ to the free atmosphere at a height of $h$.

An asymptotic solution to a first order of accuracy of Eq. (1) is (Ma and Daggupaty, 1998)

$$
\begin{aligned}
& c \approx c_{0}\left(\frac{K_{c 0}}{K_{c}}\right)^{1 / 4} \exp \left[\frac{1}{2} \int_{z 0}^{z} \frac{\bar{w}}{K_{c}} d Z-\int_{z 0}^{z}\left(\frac{\Gamma}{K_{c}}\right)^{1 / 2} d Z\right] \\
& \left.\exp \left\{-i m\left[\left(y-y_{0}\right)+\frac{1}{2 \sqrt{\Gamma}} \int_{z 0}^{z} \frac{\bar{v}}{\left(K_{c}\right)^{1 / 2}} d Z\right]\right]\right\}
\end{aligned}
$$

where $K_{c 0}$ is the eddy diffusivity at the height of $z 0 . c_{0}$ is determined from the lower boundary condition: $c(x, z)=c_{0}$ at $\mathrm{z}=\mathrm{z} 0 . m$ is a wave number, taken as $m=\pi / 4 \lambda$, where $\lambda$ is a horizontal scale of the atmospheric transport of a chemicalladen air, taken as $5000 \mathrm{~km}$ in an illustrative discussion in the following section. The real part of Eq. (6) determines the changes in air concentration in the vertical subject to the vertical diffusion and vertical motion. The imaginary part determines the horizontal variation in air concentration subject to horizontal winds and vertical diffusion. The overall decay rate constant appears in both horizontal and vertical variation terms, suggesting that the air/soil (surface) exchange affects the change in air concentration in the vertical and horizontal.

The real part solution of Eq. (6) can be written as

$$
\begin{aligned}
& \Re(c) \approx c_{0}\left(\frac{K_{c 0}}{K_{c}}\right)^{1 / 4} \exp \left[\frac{1}{2} \int_{z 0}^{z} \frac{\bar{w}}{K_{c}} d Z-\int_{z 0}^{z}\left(\frac{\varsigma}{K_{c}}\right)^{1 / 2} d Z\right] \\
& \cos \left\{m\left[\frac{1}{2 \sqrt{\varsigma}} \int_{z 0}^{z} \frac{\bar{v}}{\left(K_{c}\right)^{1 / 2}} d Z+\left(y-y_{0}\right)\right]\right\}
\end{aligned}
$$

where $\Re(c)$ indicates the real part of the air concentration defined in Eq. (6). It must be noted that Eq. (7) holds only for the first harmonic of cosine function. Equations (6) and (7) indicate that, with a ground source, the air concentration of semi-volatile chemicals will increase exponentially in the vertical with the atmospheric ascending (upward) motion $\bar{w}>0$, and decrease with the descending motion $\bar{w}<0$.
For the non-steady state $(\partial c / \partial t \neq 0)$, we used 2 -D version of the Canadian Model for Environmental Transport of Organochlorine Pesticides (CanMETOP, Ma et al., 2003; Zhang et al., 2008; Tian et al., 2009). The CanMETOP is a three-dimensional dispersion model coupled with a Level IV fugacity-based mass balance soil-air exchange model with three soil layers (Ma et al., 2003) which is used to determine the extent of dis-equilibrium and the magnitude of the soilto-air transfer. The CanMETOP also couples with a two-film model to estimate water-air gas exchange, and an air-snow (ice) exchange model (Hansen et al., 2006). Gas, solid and liquid partitioning in these exchange processes are referred to Ma et al. (2003). The model has 14 atmospheric levels from the surface to $14 \mathrm{~km}$ height on a terrain-following coordinate. The 3-D CanMETOP results are reported in the second part of this paper (Zhang et al., 2009).

Although the CanMETOP is capable of simulating ocean water/air exchange of SVOCs (Tian et al, 2009), in the present 2-D modeling simulations the zonally averaged roughness lengths and land-sea marks over the Northern Hemisphere used in the 2-D CanMETOP show that almost all underlying surfaces are land surfaces except for a few of model grids in the Arctic. Therefore, the poleward atmospheric transport from low to high latitudes occurs mostly over land surfaces in the 2-D model atmosphere. The water/air exchange takes place only in those Arctic model grids. Because the water/air exchange is a molecular exchange process within a thin layer above a water surface (Liss and Slater, 1974) and cannot be extended to the free atmosphere, this exchange process would not exert a significant influence on SVOCs' atmospheric transport and cold trapping in the mid-troposphere. A sensitive analysis indicates that the mean bias of the total mass of modeled daily $\alpha-\mathrm{HCH}$ in the 2-D model atmosphere from 1981-2000 with and without the water/air exchange included is less than $10^{-4}$.

\section{Results and discussions}

\subsection{Steady state 2-D transport}

As an illustrative case, we calculated $\alpha-\mathrm{HCH}$ air concentration using Eq. (6), driven by the mean meridional wind and vertical velocity plotted in Fig. 2, averaged over the springs of 1950 through 1980 and over the Northern Hemisphere. The spring mean meridional circulation is considered because spring is the season when the poleward atmospheric LRT is strongest (Zhang et al., 2008, 2009), and the atmospheric circulation also exhibits main characteristics of annual circulation pattern. An annual-averaged meridional atmospheric circulation over 1950-1999 is also applied in 2-D CanMETOP modeling, as will be presented below. The resulted air concentration profile of $\alpha-\mathrm{HCH}$, overlaid by wind vectors of $\bar{v}$ and $\bar{w}$, is depicted in Fig. 3. As seen, higher air concentrations correspond to the updraft of the Hadley cell 


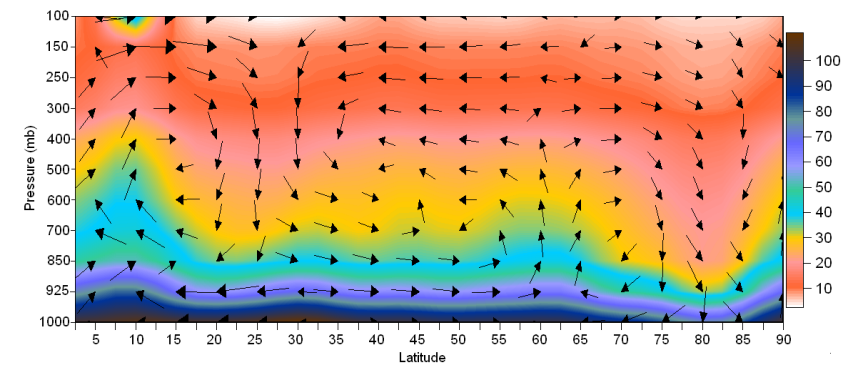

Fig. 3. Vertical profile of computed $\alpha-\mathrm{HCH}$ air concentration using Eq. (6), superimposed with vector winds of $v$ and $w$ component shown in Fig. 2. In the presentation of the vector winds, the vertical velocity $\mathrm{w}$ is multiplied by 100 .

near the equator $\left(5-10^{\circ} \mathrm{N}\right)$ and the region dominated by ascending motions between the Ferrel cell and Polar cell (60$65^{\circ} \mathrm{N}$ ). The tropical convection associated with the updraft of the Hadley cell is so strong that it carries large amount of air concentrations up to $100-\mathrm{hPa}(15000 \mathrm{~m})$. The air temperature at that level is as low as $-50 \sim-60^{\circ} \mathrm{C}$, far below the air temperature favouring solid phase of a SVOC. Given that the vertical motion displayed in Fig. 2 is averaged over springs from 1950 to 1980 , we would expect stronger vertical motions during a sporadic weather event (Zhang et al., 2009).

\subsection{Non-steady state 2-D transport}

Figure 4 displays modeled $\gamma$-HCH air concentration profile on day 100 (a), 365 (b) and 730 (c) from the non-steady state 2-D CanMETOP, derived initially from a $\gamma$-HCH soil residue of 1 ton over a tropical region from $5^{\circ}-20^{\circ} \mathrm{N}$, and driven by the spring mean meridional atmospheric circulation. Because the meridional wind, vertical velocity and air temperature do not change on a daily basis, the mean vector winds and air temperature (black solid line) are superimposed only on Fig. 4a. The air concentration rises from its source in tropical latitudes via the updraft of the Hadley cell. It enters subsequently the major atmospheric transport route to the polar region by southerly winds, laying at the 700-3000 m height (Fig. 4a). This poleward transport route rises to the $3000 \mathrm{~m}$ atmospheric level after about 200 days of model integration, as seen in Fig. $4 \mathrm{~b}$ and c. The mean air temperature at this level is $0^{\circ} \mathrm{C}$ over tropical regions. The same temperature can be observed near the surface in the sub-Arctic $\left(60^{\circ} \mathrm{N}\right)$. The corresponding vapour pressure at this height and the Arctic, shown by black solid lines in Fig. 4 b, ranges from $0.005-0.001 \mathrm{~Pa}$. In Fig. $4 \mathrm{~b}$ we also plot the modeled spatial trend of the mean soil/air fugacity ratio $\left(f_{s} / f_{a}\right)$, calculated for the soil layer at $1-10 \mathrm{~cm}$ and the air at the height of $10 \mathrm{~m}$, averaged over the first year of the model integration. Outgassing $\left(f_{s} / f_{a}>1\right)$ dominates the soil/air exchange in the tropical source region and deposition $\left(f_{s} / f_{a}<1\right)$ occurs over the rest latitudes, especially

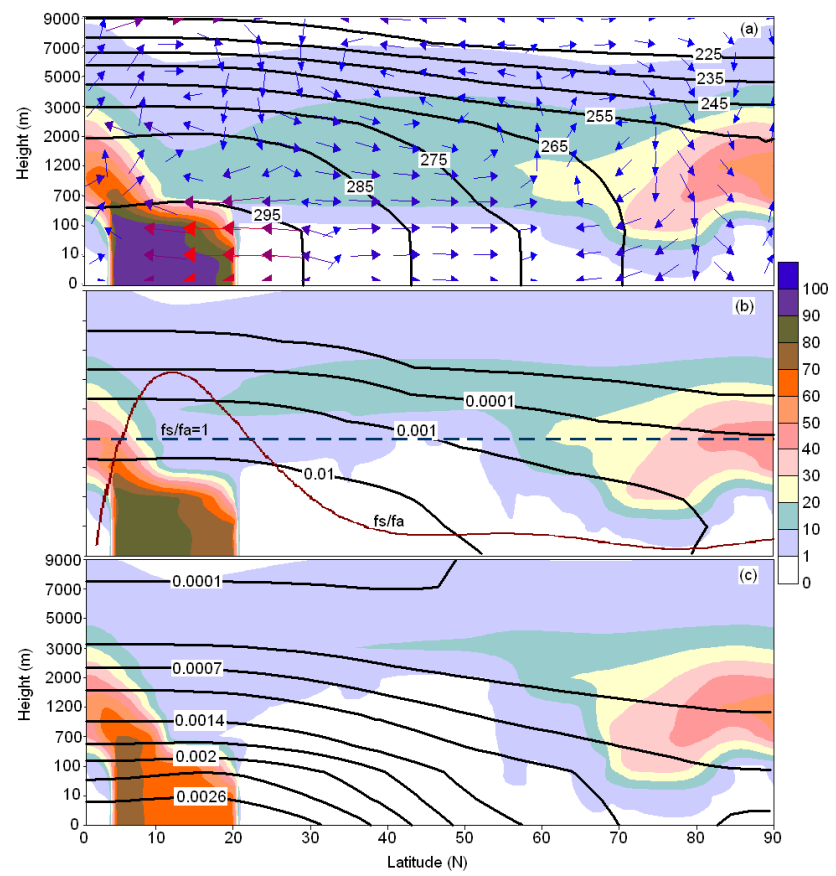

Fig. 4. Vertical cross section of modeled $\gamma-\mathrm{HCH}$ air concentration on day 100 (a), day 365 (b) and day 730 (c). Air concentration is superimposed by mean vector winds and air temperature, averaged over 1950-1980 and over the Northern Hemisphere (a), temperature dependent vapour pressure (black solid line) and trend of annual averaged soil/air fugacity ratio (deep red solid line, dish line indicating $\mathrm{f}_{s} / \mathrm{f}_{a}=1$ ) (b), and Henry's law constant (c) of $\gamma-\mathrm{HCH}$. In the presentation of the vector winds, the vertical velocity $w$ is multiplied by 100 .

the Arctic. Giving a mean water concentration of $\gamma-\mathrm{HCH}$ at $0.45 \mathrm{ng} \mathrm{L}^{-1}$ in Arctic oceans (Macdonald et al., 2000), the modeled gridded water/air fugacity ratios in the Arctic shows outgassing after one year integration (Figure not shown), in contrast to the soil / air exchange because the initial soil residues of $\gamma-\mathrm{HCH}$ are set to zero in this study. The $\gamma$-HCH-laden air sinks only over the Arctic by a strong downward motion - a signature of the downdraft of the Polar cell. In contrast, air concentration is considerably lower near the surface over a broad range from $20-60^{\circ} \mathrm{N}$ as compared with higher air concentrations in the mid-troposphere, indicating that the atmospheric transport of the chemical to the Arctic under the mean meridional atmospheric circulation is a "one-hop" pathway (Macdonald et al., 2004).

Although the air concentration over the source region declines due to degradation, high air concentration remains in the Arctic under lower air temperatures. Figure 5 displays modeled daily air concentration at $100 \mathrm{~m}$ height over a fiveyear period at $30^{\circ}, 60^{\circ}$, and $80^{\circ} \mathrm{N}$, respectively. The lowest air concentration is observed at $30^{\circ} \mathrm{N}$, corresponding to a wind divergence below the $700 \mathrm{~m}$ height (Fig. 4a). Under the mean meridional circulation the air concentration reaches the 
Table 1. Physical/chemical properties of $\mathrm{HCB}$ and $\mathrm{HCHs}$ at air temperature of $20-25^{\circ} \mathrm{C}^{*}$.

\begin{tabular}{llll}
\hline & HCB & $\alpha-\mathrm{HCH}$ & $\gamma-\mathrm{HCH}$ \\
\hline Molecular mass $\left(\mathrm{g} \mathrm{mol}^{-1}\right)$ & 284.8 & 290.85 & 291 \\
Molar volume $\left(\mathrm{cm}^{3} \mathrm{~mol}^{-1}\right)$ & 166.8 & 243.6 & 243 \\
Solid solubility in water $\left(\mathrm{g} \mathrm{m}^{-3}\right)$ & 1.2 & 1.0 & 7.3 \\
log KOA & 7.38 & 7.38 & 7.74 \\
Degradation half life in soil (day) & $2300-3650$ & 800 & 730 \\
Degradation lifetime in air (day) & $730-940$ & $15-120$ & 90 \\
Activation energy in air $\left(\mathrm{J} \mathrm{mol}^{-1}\right)$ & 24300 & 11200 & 14200 \\
Activation energy in soil $\left(\mathrm{J} \mathrm{mol}^{-1}\right)$ & 30000 & 46000 & 30000 \\
Henry's law constant $\left(\mathrm{Pa} \mathrm{m}^{3} \mathrm{~mol}^{-1}\right)$ & 131 & 0.872 & 0.309 \\
\hline
\end{tabular}

* Values of $\Delta \mathrm{E}$ in water were chosen the same as that in soil; Mackay et al. (1997), Schenker (2005); Xiao et al., (2004); Brubaker and Hites (1998); Toose et al. (2004).

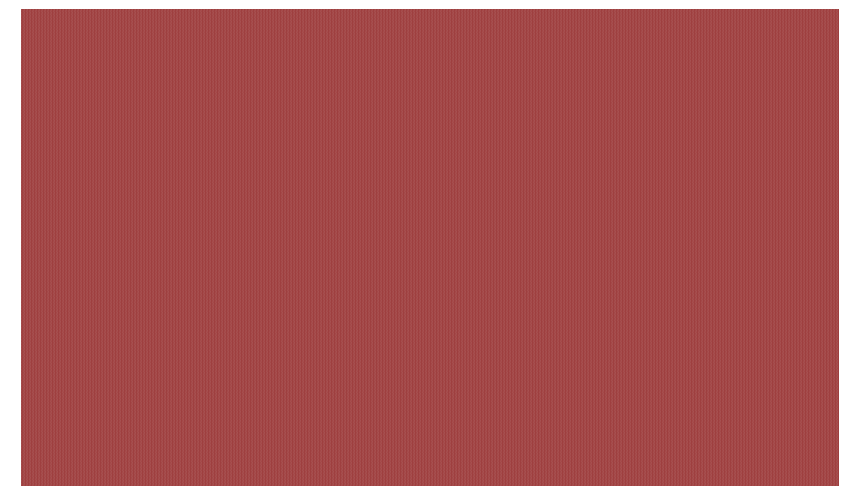

Fig. 5. Daily time series of modeled $\gamma-\mathrm{HCH}$ air concentration at $30^{\circ}, 60^{\circ}$ and $80^{\circ} \mathrm{N}$ over a 5 years period.

highest level at $60^{\circ} \mathrm{N}$ after 3 weeks from its source over 5$20^{\circ} \mathrm{N}$ and declines thereafter. Although we only input the soil residue at the beginning of model integration, after a continuous decrease for the first two years, the air concentration at $80^{\circ} \mathrm{N}$ shows an increasing trend. This increasing trend in the high Arctic reflects the persistence and accumulation of the chemical under lower air temperatures. On the other hand, strong downward atmospheric motion centered in $80^{\circ} \mathrm{N}$ (Fig. 4a) carries $\gamma-\mathrm{HCH}$-laden air from higher atmospheric level (mid-high troposphere) to the lower atmosphere, thereby increasing the atmospheric level of the chemical.

Further insight into the poleward atmospheric transport under the mean meridional atmospheric circulation can be gained from 2-D CanMETOP modeling of $\alpha-\mathrm{HCH}$ and hexachlorobenzene (HCB). Compared with $\gamma-\mathrm{HCH}$, these two chemicals are more persistent and volatile. Their physical / chemical properties are listed in Table 1. Instead of using the spring mean meridional atmospheric circulation as shown in Fig. 2, in this modeling exercise an annual mean meridional - vertical atmospheric circulation in the Northern Hemisphere, averaged over 1950-1999 using the NCEP

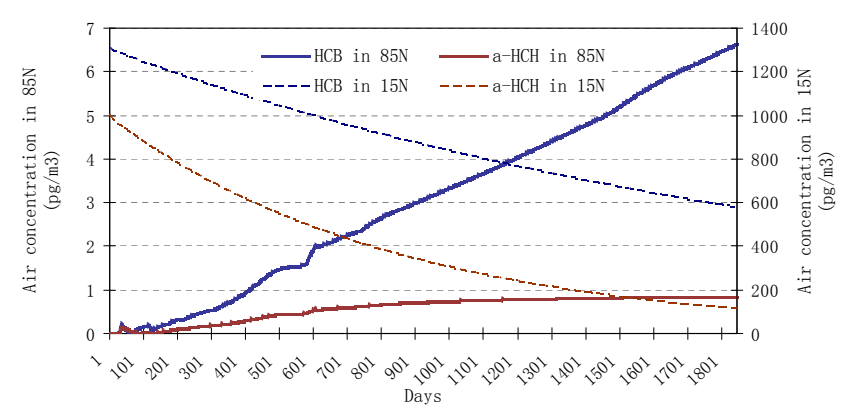

Fig. 6. Modeled daily air concentration of $\alpha-\mathrm{HCH}$ and HCB at the $10 \mathrm{~m}$ height during a 5 years period in $15^{\circ} \mathrm{N}$ and $85^{\circ} \mathrm{N}$, respectively.

reanalysis, was employed to drive the 2-D CanMETOP. Figure 6 shows modeled daily air concentration of $\alpha-\mathrm{HCH}$ and $\mathrm{HCB}$ at the $10 \mathrm{~m}$ height over a 5 years period in $15^{\circ} \mathrm{N}$ and $85^{\circ} \mathrm{N}$, respectively. In analogous to the 2-D modeling for $\gamma-\mathrm{HCH}$, in the first instance we once again input the soil residue of 1 ton at each model grid ( $1^{\circ}$ degree of latitude) from $5^{\circ}-20^{\circ} \mathrm{N}$ as a source of $\alpha-\mathrm{HCH}$ and $\mathrm{HCB}$. As seen, at the tropical source location $\left(15^{\circ} \mathrm{N}\right)$, both chemicals show a decreasing trend due to degradation. Given its stronger persistence and volatility, HCB exhibits higher air concentration than $\alpha-\mathrm{HCH}$. Higher air concentration of HCB is also clearly seen in the high Arctic $\left(85^{\circ} \mathrm{N}\right)$, although both chemicals are delivered to the Arctic under the same atmospheric circulation and using the same soil residues. The results also provide modeling evidence for the global fractionation effect, referred to the relative transport efficiencies of the two compounds (Wania and Mackay, 1996; Scheringer et al., 2002). Indeed, the stronger persistence and volatility of HCB (Table 1) leads to the highest long-range transport potential of HCB (Beyer et al., 2000) and higher concentration of HCB in the Arctic air (Su et al., 2006).

We further examined the LRT of a SVOC to the Arctic by using the gridded global soil residues of $\alpha-\mathrm{HCH}$ in $1980(\mathrm{Li}$ 


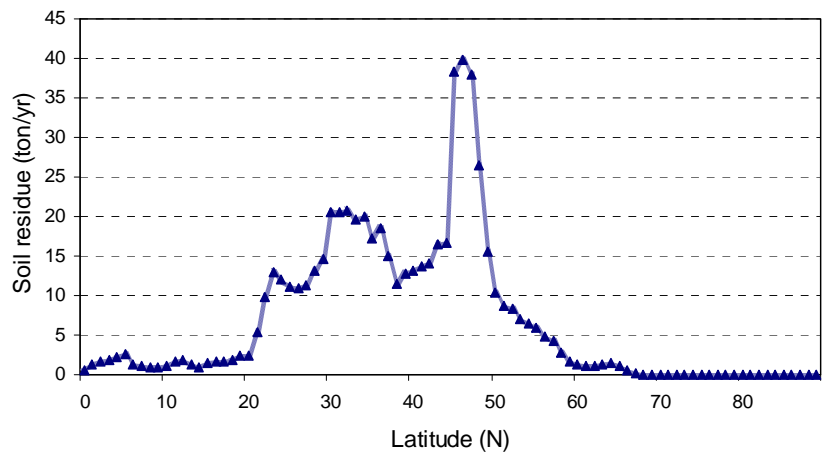

Fig. 7. Mean $\alpha-\mathrm{HCH}$ soil residue (ton $\mathrm{yr}^{-1}$ ) in 1980 , zonallyaveraged over the Northern Hemisphere.

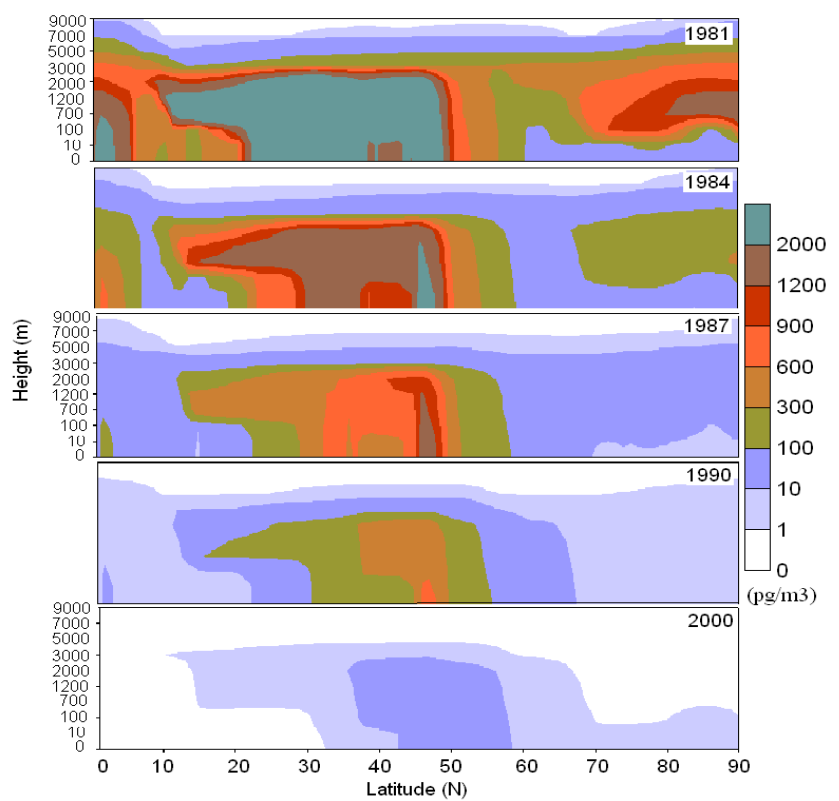

Fig. 8. Vertical cross section of modeled $\alpha-\mathrm{HCH}$ air concentration $\left(\mathrm{pg} \mathrm{m}^{-3}\right)$ from 1981 to 2000 using the mean soil residue over the Northern Hemisphere in 1980 (Fig. 7).

et al., 2000), the year with the highest global soil residue of $\alpha-\mathrm{HCH}$. These residues are then zonally-averaged over the Northern Hemisphere. The averaged inventory shows two peak values of the soil residues near $32^{\circ} \mathrm{N}$ and $46^{\circ} \mathrm{N}$, respectively (Fig. 7). By implementing this soil residue inventory into the 2-D CanMETOP, the model was integrated over a 20 years period from 1980 to 2000 under the annual mean meridional atmospheric circulation. Figure 8 illustrates modeled vertical profile of the air concentration of $\alpha-\mathrm{HCH}$ for the selected years from 1980-2000. The highest concentrations of the chemical correspond to its major sources in the soils, as seen in Fig. 7. Higher air concentrations near the source latitudes extend from surface to the mid-troposphere, indicating again that the mid-troposphere is an important pathway and reservoir of SVOCs. At higher levels of the Arctic atmo-

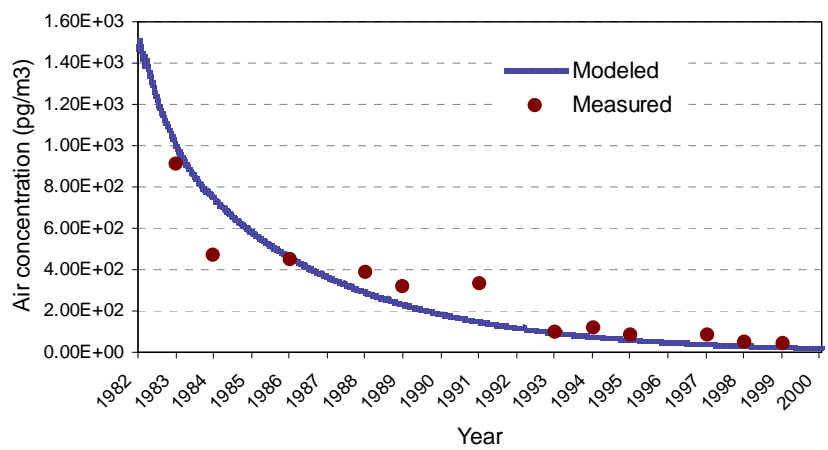

Fig. 9. Modeled and measured atmospheric concentration of $\alpha$ $\mathrm{HCH}$ averaged over the Arctic.

sphere, the air concentration of $\alpha-\mathrm{HCH}$ in 1981 and 1984 exhibits a similar pattern as that of $\gamma-\mathrm{HCH}$, as shown by Fig. 4, though different soil residues were used. The higher air concentrations over the tropical region (from 1981-1984 in Fig. 8) was conveyed largely from one of the major sources near $32^{\circ} \mathrm{N}$ (Fig. 7) via an equator-ward returning flow of the Hadley cell near the surface (Fig. 2). The figure also clearly shows that, except for the major source region in the midlatitudes (Fig. 7), relatively higher air concentrations remain in the low atmosphere over the Arctic whereas in the low latitudes the significant level of $\alpha-\mathrm{HCH}$ in air is no longer identified due partly to its shorter life time in tropical environments. Note that in this modeling exercise we used only the $\alpha-\mathrm{HCH}$ soil residue in 1980 whereas this pesticide was still used till the early 1990s (Li et al., 2000). Overall, the model successfully simulated major characteristics of the poleward atmospheric transport and the cold trapping effect of this chemical under the mean meridional atmospheric circulation.

\subsection{Model evaluation}

With zonally-averaged soil residues the modeled atmospheric concentrations of $\alpha-\mathrm{HCH}$ shown in Fig. 8 were, in fact, the zonally averaged air concentrations over the Northern Hemisphere. The modeled mean air concentrations of the selected SVOCs cannot be properly compared with monitored air concentration at a single site. Due to rather homogeneous distribution of $\mathrm{HCHs}$ in air throughout the Arctic (Pacyna and Oehme, 1988; Wania and Mackay, 1993; Su et al., 2006), it is perhaps more appropriate to compare the modeled mean air concentration of $\alpha-\mathrm{HCH}$ with the measured data collected in the Arctic (Li et al., 2004). Results are presented in Fig. 9. The model appears to underestimate the atmospheric level of $\alpha-\mathrm{HCH}$ as compared with the measurements (Fig. 9). The underestimations are likely resulted from ignoring $\alpha-\mathrm{HCH}$ emissions after 1980. The modeled temporal trend seems to, however, agree well with the measurements. 
Only a few attempts to measure a SVOC in the midtroposphere were made (Knap and Binkley, 1991; Harner et al., 2005). Assuming that atmospheric concentration of $\alpha-\mathrm{HCH}$ in the free atmosphere was uniformly distributed in the same latitude, the model simulated $\alpha-\mathrm{HCH}$ air concentrations using the mean $\alpha-\mathrm{HCH}$ soil residue in 1985 (Fig. 7) at 700 to $3000 \mathrm{~m}$ height can be evaluated against the aircraft measured $\alpha-\mathrm{HCH}$ air concentrations reported by Knap and Binkley (1991). Compared with the measured air concentration at $380 \mathrm{pg} \mathrm{m}^{-3}$ in April 1985 and $303 \mathrm{pg} \mathrm{m}^{-3}$ over the western North Atlantic south-east of Bermuda (roughly at $32^{\circ} \mathrm{N}$ ) at higher atmosphere up to $3000 \mathrm{~m}$, our modeled mean concentrations in the same latitude and during the same period are 860 and $495 \mathrm{pg} \mathrm{m}^{-3}$, respectively. The aircraft measured $\alpha-\mathrm{HCH}$ air concentration by Knap and Binkley (1991) in the end of July 1985 over Adirondacks ( $44^{\circ} \mathrm{N}$ ), New York ranged from 330 to $500 \mathrm{pg} \mathrm{m}^{-3}$, which are again comparable with the modeled mean concentration at $830 \mathrm{pg} \mathrm{m}^{-3}$ over the same latitude at 1000 to $3000 \mathrm{~m}$ height. Harner (2005) et al have reported the aircraft measured $\alpha-\mathrm{HCH}$ air concentration ranging from $1-61 \mathrm{pg} \mathrm{m}^{-3}$ at the $4400 \mathrm{~m}$ height in August 2001 at Fraser Valley near the west coast of Canada, with the mean air concentration at $23 \mathrm{pg} \mathrm{m}^{-3}$ at this atmospheric elevation. This is comparable with our modeled concentration $\left(5-30 \mathrm{pg} \mathrm{m}^{-3}\right)$ at the height of $3000-5000 \mathrm{~m}$ in $50^{\circ} \mathrm{N}$ in 1990 (Fig. 7). In 2000, however, our model concentration at the same level in $50^{\circ} \mathrm{N}$ declines below $5 \mathrm{pg} \mathrm{m}^{-3}$. This again can be attributed to neglect the $\alpha-\mathrm{HCH}$ emission after 1980 .

Modeled $\alpha-\mathrm{HCH}$ air concentration were also compared with the data reported by van Drooge et al. (2002). Atmospheric sampling of HCHs, HCB and PCBs was conducted on the remote Mount Teide on Tenerife $\left(\sim 28^{\circ} \mathrm{N}\right)$ with an air sampler located at $\sim 2370 \mathrm{~m}$ atmospheric height above the sea level from June 1999 to July 2000. Measured mean air concentration of $\alpha-\mathrm{HCH}$ at this sampling site was $5.9 \mathrm{pg} \mathrm{m}^{-3}$ (van Drooge et al., 2002). During the same period, our modeled atmospheric level of $\alpha-\mathrm{HCH}$ is $2.7 \mathrm{pg} \mathrm{m}^{-3} \mathrm{~m}$ at the $2000 \mathrm{~m}$ atmospheric height. However, although the modeled atmospheric concentration is generally consistent with the measurement, it is noted that this measurement was taken on a $15 \mathrm{~m}$ high tower above the surface (van Drooge et al., 2002) of the high mountain, rather than in the free troposphere which is defined as the portion of the troposphere above the PBL $(\sim 1000 \mathrm{~m}$ above a surface rather than above the sea level). In the free troposphere, the effect of the surface fraction on air motion is negligible.

Because the artificial soil residues of $\gamma-\mathrm{HCH}$ and HCB were used in the 2-D modeling, the modeled zonally averaged atmospheric concentration of these two substances are not comparable with measurements.

\section{Cold trapping - partition at a cold, higher atmosphere}

Little is known about the partitioning of SVOCs between gas and aqueous or particle phase in the mid and hightroposphere. It is known that many gas phase SVOCs may not be sorbed efficiently to the Arctic aerosols during the warm period of a year (Macdonald et al., 2000). The SVOCs' sorption to aerosols in the mid-troposphere over the warm latitudes is likely also not a very efficient pathway for the gas to particle phase partitioning due partly to lower aerosol concentration at higher atmospheric altitudes. Compared with the Arctic environment where solid particle and aqueous phases include aerosols, rain, fog, snow, soil, vegetation, water surface etc, there are only a few of sorbing media in the troposphere. Except for atmospheric aerosols, water droplets and ice particles, formed mostly in clouds, are likely important sorbents in the mid-troposphere. Cloud measurements have shown increase in concentration of water droplets and ice particles with atmospheric altitudes below the midtroposphere (Rogers and Yau, 1989; Lawrence and Crutzen, 1998). The uptake of pollutants by cloud ice particles and water droplets has been known to be an important pathway of the pollutants in the atmosphere (Lawrence and Crutzen, 1998). However, the knowledge for the uptake of SVOCs by cloud ice particles and water droplets is still poor. Lei and Wania (2004) have discussed organic chemical uptake in the rain droplets and snow. The chemical uptake in the rain droplets takes place by dissolution in the liquid phase and sorption to the droplet surface (Goss, 1994, 1997, 2004; Lei and Wania, 2004). It can be reasonably assumed that the uptake mechanism in the rain droplets is identical to the uptake in cloud water droplets. Thus, the method to compute the partitioning between air and rain droplets of organic chemicals can be directly applied in estimate of air-cloud droplet partitioning. Following Lei and Wania, the air-cloud droplet partitioning, expressed as the ratio between the equilibrium concentrations in the cloud droplets and the gas phase of a chemical, is calculated by

$K_{\text {Droplet } / \text { Air }}=K_{\mathrm{WA}}+3 K_{\mathrm{IA}} / r$,

where $K_{W A}$ is dimensionless and calculated by $K_{W A}=R T / H$, $T$ is air temperature (K), $R$ is the ideal gas constant, and $r$ is the radius of a cloud droplet, taken as $1 \mathrm{~mm}$ in this study (Lei and Wania, 2004). $K_{I A}(\mathrm{~m})$ in Eq. (6) is an interfaceair partitioning coefficient, defined as the ratio of the interfacial concentration in units of $\mathrm{mol} \mathrm{m}^{-2}$ of surface and the gas phase concentration in units of mol m $\mathrm{m}^{-3}$ of air, computed by (Goss, 1997; Hoff et al., 1995; Wania et al., 1998; 1999),

$\lg K_{\mathrm{IA}}(T)=\lg K_{\mathrm{IA}}\left(T_{\mathrm{ref}}\right)-\frac{\Delta H_{S}}{R}\left(\frac{1}{T}-\frac{1}{T_{\text {ref }}}\right)$,

where $\Delta H_{s}$ is the enthalpy of sorption (values of $\Delta H_{s}$ referred to Lei and Wania, 2004) and $T_{\text {ref }}$ is the reference temperature. Figure 10 displays computed vertical profile of 

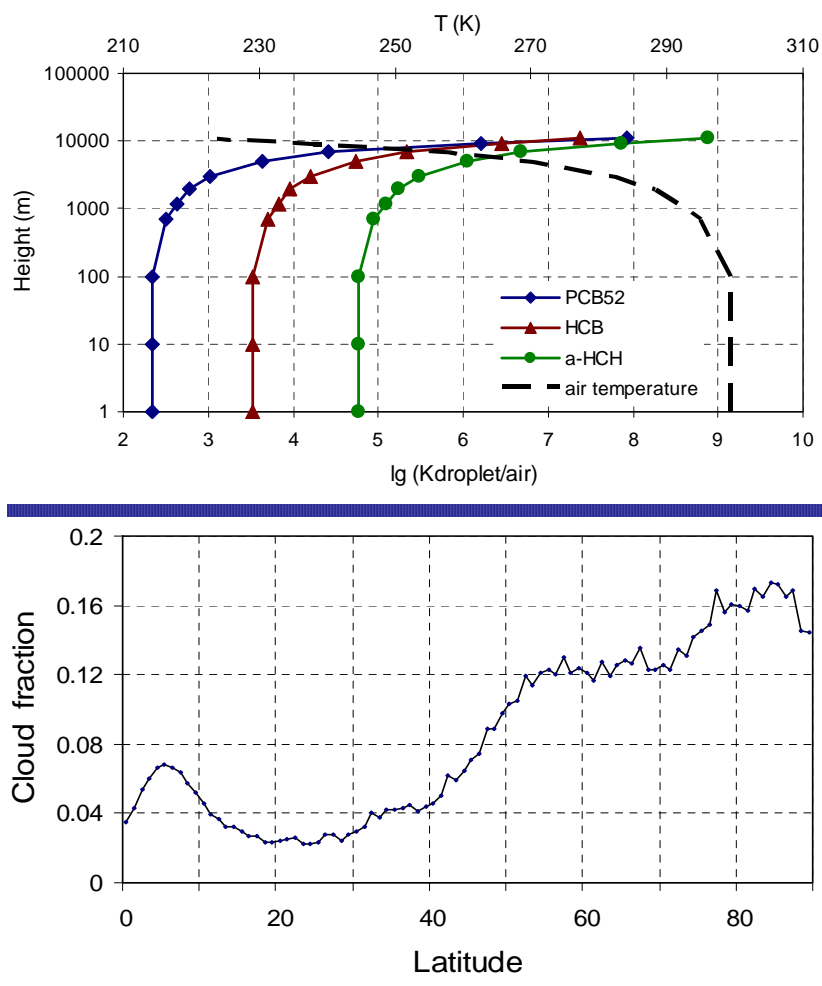

Fig. 10. (a) Vertical profile of temperature dependent air-cloud

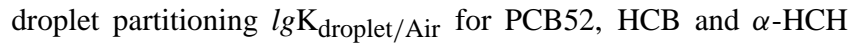
at $10^{\circ} \mathrm{N} . \lg \mathrm{K}_{\text {Droplet/Air }}$ at value of 5.5-7.5 indicates the transition from vapour to aqueous phase. The vertical profile in the zonallyaveraged mean air temperature, averaged over 1950-1980, as shown in Fig. 1, is also presented (black dashed line). The upper $\mathrm{x}$-axis indicates air temperature and lower $\mathrm{x}$-axis indicates $\lg \mathrm{K}_{\text {Droplet/Air }}$. (b) Modeled mean annual cloud fraction (\%) at $3000 \mathrm{~m}$ height averaged over the Northern Hemisphere.

$\lg \mathrm{K}_{\text {Droplet/Air }}$ of PCB52, $\mathrm{HCB}$ and $\alpha-\mathrm{HCH}$ in the tropical latitude $10^{\circ} \mathrm{N}$. The vertical profile of the mean air temperature, zonally-averaged over the Northern Hemisphere and averaged over 1950-1980 is also shown in Fig. 10a. The $\lg K_{\text {Droplet/Air }}$ values of the three chemicals exhibit a slow change within the atmospheric boundary-layer (lower troposphere) because of strong vertical turbulent mixing of air temperature and the chemicals due to the underlying surface fraction and heating, but increase rapidly above the lower troposphere, corresponding to the rapid decline in air temperature. Lei and Wania (2004) suggest that the transition from vapour to aqueous phase occurs at $\lg K_{\text {Droplet/Air }}$ of 5.5-7.5. Our results indicate that, for PCB52 and HCB, such transition occurs at the height of 7000-9000 m. For $\alpha-\mathrm{HCH}$, the vapour to aqueous phase transition takes place at the 3000$9000 \mathrm{~m}$ height, corresponding nicely to the height of the atmospheric transport route from the tropical source region to the Arctic in the mid and high-troposphere (Fig. 8). By coupling a cloud model (Sundquist et al., 1989) with the CanMETOP, we have calculated cloud fraction and cloud liq- uid water content (LWC). Fig. 10b shows the profile of annual mean cloud fraction at the $3000 \mathrm{~m}$ atmospheric height, zonally averaged over the Northern Hemisphere. Highest cloud fraction can be seen over the high Arctic between 80$90^{\circ} \mathrm{N}$, due primarily to the lower air temperatures in the Arctic atmosphere which favor condensation of humid air mass. Subtropical region from $20-30^{\circ} \mathrm{N}$ exhibits the lowest cloud fraction, corresponding to the downdraft of the Hadley cell (Fig. 2). Because the partitioning at the air-ice interface can be approximated by extrapolating adsorption constants for the air-water interface (Hoff et al., 1995; Wania et al., 1998, 1999), the air-ice particle partitioning is not presented here. An estimation of the uptake of the three chemicals in ice (snow) (Lei and Wania, 2004) shows that the vapour to (snow or ice) aqueous phase transition for the three chemicals occurs at the 5000-9000 $\mathrm{m}$ atmospheric heights.

Clouds cover about $60 \%$ of the sky and formed over both lower latitudes due to strong convections and higher latitudes due to cold environments (Rogers and Yau, 1989). The atmospheric convections not only carry the warm and humid air parcels to a higher atmosphere level where the air parcels are condensed to a solid phase thereby forming clouds, but also lift chemicals to the higher altitude. Enrichment of clouds in the Arctic atmosphere (Fig. 10b), in particular, suggests that the cold trapping of SVOCs is very likely to occur at a higher atmospheric elevation over the Arctic, as shown by Figs. 4 and 8. The water droplets and ice particles in clouds may act as major sorbing media and provide an efficient pathway for the cold trapping in the mid-troposphere. The partitioning processes between SVOCs and cloud droplets and ice particles are possibly similar to that in snow and ice (Hoff et al., 1995; Wania et al., 1998). The change in size and specific surface area of droplets and ice particles, height, area, properties, and volume of a cloud may make the issue more complex to be understood. Further studies in understanding the sorption and partition of SVOCs onto cloud droplets and ice particles are needed.

\section{Deposition vs. vertical motion}

Because the increased vapour to particle and aqueous phase partitioning in the atmosphere gives rise to an increase in deposition rate, in the explanation of cold trapping effect the atmospheric deposition of SVOCs has been thought to be of equal importance as their partition in cold, higher latitudes and the polar region. The atmospheric deposition consists of wet and dry deposition. Dry particle deposition in a neutral atmosphere can be defined by

$$
v_{d}=\frac{\kappa F_{m}^{1 / 2}}{\ln \frac{z}{z 0}+2\left(\frac{S_{r}}{P_{r}}\right)^{2 / 3}},
$$

where $F_{m}$ is the surface momentum flux, $S_{r}$ is the Schmidt number, and $P_{r}$ is the turbulent Prandtl number, respectively. 

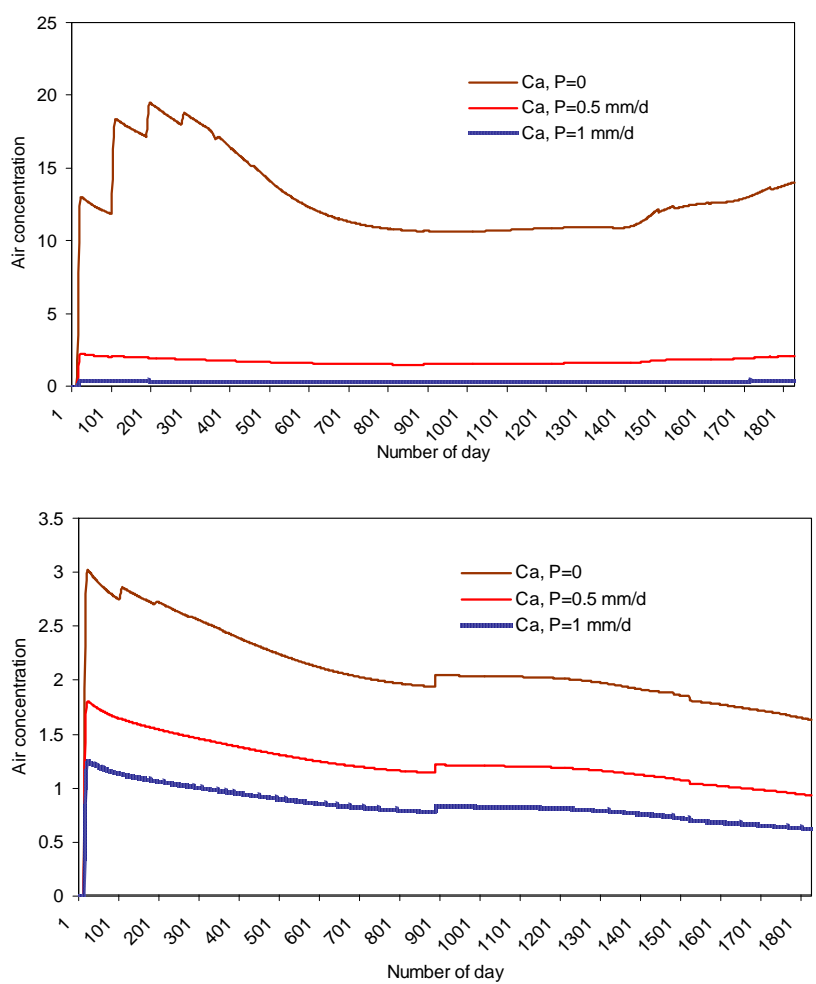

Fig. 11. Daily time series of modeled air concentration $(\mathrm{Ca})$ of $\gamma$ $\mathrm{HCH}$ at $80^{\circ} \mathrm{N}$ for a 5 years period from non-steady state solution of Eq. (1) responding to the precipitation scavenging at daily precipitation rate 0.5 and $1 \mathrm{~mm} \mathrm{~d}^{-1}$ at (a) 10 and (b) $3000 \mathrm{~m}$ height.

Given that the logarithmic relationship for air concentration (and wind, air temperature and humidity) applies only in the surface atmospheric boundary-layer (below $100 \mathrm{~m}$ in the neutral atmosphere), the surface momentum flux tends to vanish above this layer. Thus, the above expression clearly indicates that dry deposition occurs only within the surface boundarylayer. It turns out that, if a chemical moves in the midtroposphere, dry deposition does not contribute to its loading to the surface unless it reaches the surface boundary-layer by other atmospheric processes (e.g., downward motion and wet deposition).

On the other hand, precipitation scavenging takes place in precipitation and fog events throughout the vertical atmosphere, resulting in wet deposition. To examine the effect of wet deposition on vertical profile of the chemical's air concentration, two modeling scenarios through the assumption of daily precipitation rates at $1 \mathrm{~mm} \mathrm{~d}^{-1}$ and $0.5 \mathrm{~mm} \mathrm{~d}^{-1}$ over the Arctic in 2-D CanMETOP was conducted. These two precipitation rates are equivalent to the annual precipitation of $365 \mathrm{~mm}$ and $187 \mathrm{~mm}$, respectively, which are comparable with the annual averaged precipitation in the Arctic (Barrie et al., 1992). We then integrate the 2-D CanMETOP for a five-year period. Figure 11 plots the modeled air concentration of $\gamma-\mathrm{HCH}$ with daily precipitation rate at $0,0.5$ and
$1 \mathrm{~mm} \mathrm{~d}^{-1}$ at $80^{\circ} \mathrm{N}$ at the $10 \mathrm{~m}$ (a) and $3000 \mathrm{~m}$ (b) height, respectively. As shown, responding to the washout by precipitation of 0.5 and $1 \mathrm{~mm} \mathrm{~d}^{-1}$, the air concentration at the $10 \mathrm{~m}$ height declines about a factor of 2 to 3 throughout the 5 years integration period, comparing with a non precipitation scenario (Fig. 11a). At a level of the mid-troposphere $(3000 \mathrm{~m})$, the scavenging by both 0.5 and $1 \mathrm{~mm}$ daily precipitation rate reduces considerably the atmospheric concentration. It can be seen from Fig. 11 that the daily precipitation rate of $0.5 \mathrm{~mm}$ leads to almost one order of magnitude reduction of the air concentration comparing with that without wet deposition. The doubling this precipitation rate further yields two orders of magnitude reduction of the air concentration in the mid-troposphere, suggesting that the wet deposition is a dominant pathway in the Arctic. Nonetheless, as another atmospheric process that is able to carry persistent chemicals from a higher atmosphere elevation to the Arctic surface, the descending motion likely occurs more frequently than the wet deposition and associates with LRT events of SVOCs.

\section{Conclusions}

While referring to the classical definition on the global distillation cold condensation process as cited in Introduction, one can depict a physical picture of the cold trapping effect under the mean meridional atmospheric circulation based on the result of the present study. In addition to those necessary conditions for the cold trapping (condensation) as proposed previously (Wania, and Mackay, 1993, 1996; Mackay and Wania, 1995), the cold trapping may occur in the midtroposphere over a source of SVOCs in lower and warm latitudes through interacting with clouds. The atmospheric convection and ascending motion in the source region carries the chemicals to the mid-troposphere where rapid decrease air temperature and clouds partition some of these chemicals from their gas-phase onto clouds ice particles and water droplets, where the chemicals become more persistent under lower temperature, and where stronger winds deliver more efficiently the chemicals to the polar region. This $2-$ D modeling study has illustrated higher air concentrations of SVOCs in the mid-troposphere emitted and transported from their sources in lower and mid-latitude soils, thereby demonstrating that the mid-troposphere is an important pathway and reservoir of SVOCs. The continuous descending motion and precipitation scavenging carry subsequently the chemicals to the surface of the Arctic ecosystem. To further demonstrate these speculative deductions, extensive modeling investigations for episodic atmospheric transport events have also been carried out and the results will be reported in an accompanying paper (Zhang et al., 2009). 
Acknowledgements. This study is funded by the International Polar Year program: Intercontinental Atmospheric Transport of Anthropogenic Pollutants to the Arctic.

Edited by: A. S. H. Prévôt

\section{References}

Barrie, L. A., Gregor, D., Hargrave, B., Lake, R., Muir, D., Shearer, R., Tracey, B., and Bidleman, T.: Arctic contaminants: sources, occurrence and pathways, Sci. Total Environ., 122, 1-74, 1992.

Bennett, D., Kastenberg, W., and McKone, T. E.: General formulation of characteristic time for persistent chemicals in a multimedia environment, Environ. Sci. Technol., 33, 503-509, 1999.

Beyer, A., Mackay, D., Matthies, M., Wania, F., and Webster, E.: Assessing long-range transport potential of persistent organic pollutants, Environ. Sci. Technol., 34, 699-703, 2000.

Blais, J. M., Schindler, D. W., Muir, D. C. G., Kimpe, L. E., Donaldk, D. B., and Rosenberg, B.: Accumulation of persistent organochlorine compounds in mountains of western Canada, Nature, 395, 585-588, 1998.

Brubaker, W. W. and Hites, R. A.: OH reaction kinetics of gas-phase alpha- and gamma-hexachlorocyclohexane and hexachlorobenzene, Environ. Sci. Technol., 32, 766-769, 1998.

Calamari, D., E., Bacci, S., Focardi, C., Gaggi, M., Morosini, M., and Vighi, M.: Role of plant biomass in the global environmental partitioning of chlorinated hydrocarbons, Environ. Sci. Technol., 25, 1489-1495, 1991.

Garratt, J. R.: The atmospheric boundary layer, Cambridge University Press, Cambridge, UK, 316 pp., 1992.

Goldberg, E. D.: Synthetic organohalides in the sea, Proc. R. Sot. Land. B., 189, 277-289, 1975.

Goss, K.-U.: Predicting the enrichment of organic compounds in fog caused by adsorption on the water surface, Atmos. Environ., 28, 3513-3517, 1994.

Goss, K.-U.: Conceptual model for the adsorption of organic compounds from the gas phase to liquid and solid surfaces, Environ. Sci. Technol., 31, 3600-3605, 1997.

Goss, K.-U.: The air/surface adsorption equilibrium of organic compounds under ambient conditions, Criti. Rev. Environ. Sci. Technol., 34, 339-389, 2004.

Harner, T., Shoeib, M., Kozama, M., and Li, S. M.: Hexachlorocyclohexanes and endosulfans in urban, rural, and high altitude air samples in the Fraser Valley, British Columbia: Evidence for trans-Pacific transport, Environ. Sci. Technol., 39, 724-731, 2005.

Hansen, K. M., Christensen, J. H., Brandt, J., Frohn, L. M., and Geels, C.: Modelling atmospheric transport of ?hexachlorocyclohexane in the Northern Hemispherewith a 3-D dynamical model: DEHM-POP, Atmos. Chem. Phys., 4, 11251137, doi:10.5194/acp-4-1125-2004, 2004.

Hansen, K. M., Halsall, C. J., and Christensen, J. H.: A dynamic model to study the exchange of gas-phase persistent organic pollutants between air and a seasonal snowpack, Environ, Sci. Technol., 40, 2644-2652, 2006.

Hoff , J. T., Wania, F., Mackay, D., and Gillham, R.: Sorption of non-polar organic vapors by ice and snow, Environ. Sci. Technol., 92, 1982-1989, 1995.
Holton, J. R.: An Introduction to Dynamic Meteorology, Elsevier Academic Press, MA, USA, 535 pp., 2004.

Knap, A. H. and Binkley, K. S.: Chlorinated organic compounds in the troposphere over the Western North Atlantic Ocean measured by aircraft, Atmos. Environ., 25A, 1507-1516, 1991.

Kalney, E., Kanamitsu, M., Kistler, R., et al.: The 40-year NCEP/NCAR reanalysis project, Bull. Am. Meteorol. Soc., 77, 437-471, 1996.

Koziol, A. S. and Pudykiewicz, J. A.: Global-scale environmental transport of persistent organic pollutants, Chemosphere, 45, 1181-1200, 2001.

Lawrence, M. G. and Crutzen, P. J.: The impact of cloud particle gravitational settling on soluble trace gas distributions, Tellus, 50B, 263-289, 1998.

Lei, Y. D. and Wania, F.: Is rain or snow a more efficient scavenger of organic chemicals?, Atmos. Environ., 38, 3557-3571, 2004.

Li, Y. F., Scholdz, M. T., and van Heyst, B. J.: Global gridded emission inventory of $\alpha$-hexachlorocyclohexane, J. Geophys. Res., 105(D5), 6621-6632, 2000.

Li, Y.-F., Macdonald, R. W., Ma, J., Hung, H., and Venkatesh, S.: Historical a-HCH budget in the Arctic Ocean: The Arctic Mass Balance Box Model (AMBBM), Sci. Total Environ., 324, 115139, 2004

Liss, P. S. and Slater, P. G.: Flux of gases across the air-sea interface, Nature, 247, 181-184, 1974.

Ma, J. and Daggupaty, S.: A generalized analytical solution for turbulent dispersion with inhomogeneous wind and diffusion coefficient, Environ. Model. Assess., 3, 239-248, 1998.

Ma, J., Daggupaty, S. M., Harner, H., and Li, Y.: Impacts of lindane usage in the Canadian prairies on the Great Lakes ecosystem 1: Coupled atmospheric transport model and modeled concentrations in air and soil, Environ. Sci. Technol., 37, 3774-3781, 2003.

Ma, J., Venkatesh, S., Li, Y., Cao, Z., and Daggupaty, S.: Tracking toxaphene in the North American Great Lakes basin - 2. A strong episodic long-range transport event, Environ. Sci. Technol., 39, 8123-8131, 2005.

Macdonald, R. W., Barrie, L. A., Bidleman, T. F., Diamond, M. L., Gregor, D. J., Semkin, R. G., Strachan, W. M. J., Li, Y. F., Wania, F., Alaee, M., Alexeeva, L. B., Backus, S. M., Bailey, R., Bewers, J. M., Gobeil, C., Halsall, C. J., Harner, T., Hoff, J. T., Jantunen, L. M. M., Lockhart, W. L., Mackay, D.;,Muir, D. C. G., Pudykiewicz, J., Reimer, K. J., Smith, J. N., Stern, G. A., Schroeder, W. H., Wagemann, R., and Yunker, M. B.: Sources, occurrence and pathways of contaminants in the Canadian Arctic: A review, Sci. Total Environ., 254, 93-236, 2000.

Mackay, D. and Wania, F. Transport of contaminants to the Arctic: partitioning, processes and models, Sci. Total Environ., 160/161, 25-38, 1995.

Mackay, D., Shiu, W.-Y., and Ma, K.-C.: Illustrated Handbook of Physical-Chemical Properties and Environmental Fate for Organic Chemicals, Vol 5-Pesticide Chemicals, Lewis, Boca Raton, FL, USA, 1997.

Meijer, S. M., Steinnes, E., Ockenden, W. A., and Jones, K. C.: Influence of environmental variables on the spatial distribution of PCBs in Norwegian and U.K. soils: Implications for global cycling, Environ. Sci. Technol., 36, 2146-2153, 2002.

Meijer, S. N., Ockenden, W. A., Sweetnam, A., Breivik, K., Grimalt, J. O., and Jones, K. C.: Global distribution and budget of 
PCBs and HCB in background surface soils: implications for sources and environmental processes, Environ Sci. Technol., 37, 667-672, 2003.

MONARPOP: Monitoring Network in the Alpine Region for Persistent and Other Organic Pollutants http://www.monarpop.at, last access: 15 August 2009.

Nieuwstadt, F. T. M.: On the solution of the stationary, baroclinic Ekman-layer equations with a finite boundary-layer height, Bound.-Lay. Meteorol., 26, 377-390, 1983.

Ottar, B.: The transfer of airborne pollutants to the Arctic region, Atmos. Environ., 15, 1439-1445, 1981.

Pacyna, J. M. and Oehme, M.: Long-range transport of some organic compounds to the Norwegina Arctic, Atmos. Environ., 22, 1988, 243-257, 1988.

Rahn, K. A. and Heidam, N. Z.: Progress in Arctic air chemistry 1977-1980: a comparison of the first and second symposium, Atmos. Environ., 15, 1345-1348, 1981.

Rogers, R. R. and Yau, M. K.: A short course in cloud physics: Third edition, Butterworth-Heinenmann, MA, USA, 304 pp., 1989.

Schenker, U., Macleod, M, Scheringer, M, and Hungerbuhler, K.: Improving data quality for environmental fate models: a leastsquare adjustment procedure for harmonizing physicochemical properties of organic compounds, Environ. Sci. Technol., 39, 8434-8441, 2005.

Scheringer, M.: Persistence and Spatial Range of Environmental Chemicals: New Ethical and Scientific Concepts for Risk Assessment, Wiley-VCH, Weinheim, Germany, 308 pp., 2002.

Semeena, V. S. and Lammel, G.: Effects of various scenarios of entry of DDT and - $\mathrm{HCH}$ on the global environmental fate as predicted by a multicompartment chemistry-transport model, Fresenius Environ. Bull., 12, 925-939, 2003.

Semeena, V. S. and Lammel, G.: The significance of the grasshopper effect on the atmospheric distribution of persistent organic substances, Geophys. Res. Lett., 32, L07804, doi:10.1029/2004GL022229, 2005.

Spivakovsky, C. M., Logan, J. A., Montzka, S. A., Balkanski, Y. J., Foreman-Fowler, M., Jones, D. B. A., Horowitz, L. W., Fusco, A. C., Brenninkmeijeer, C. A. M., Prather, M. J., Wofsy, S. C., and McElroy, W. B.: Three-dimensional climatological distribution of tropospheric $\mathrm{OH}$ : Update and evaluation, J. Geophys. Res., 105, 8931-8980, 2000.

Strand, A. and Hov, O.: A model strategy for the simulation of chlorinated hydrocarbon distributions in the global environment, Water Air Soil Pollut., 86, 283-316, 1996.

Stroebe, M., Scheringer, M., Held, H., Hungerbühler, K.: Intercomparison of multimedia modeling approaches: modes of transport, measures of long range transport potential and the spatial remote state, Sci. Total Environ., 321, 1-20, 2004.
Su, Y., Hung, H., Blanchard, P., Patton., G. W., Kallenborn, R., Konoplev, A., Fellin, P., Li, H., Geen, C., Stern, G., Rosenberg, B., and Barrie, L. A.: Spatial and seasonal variations of Hexachlorocyclohexanes (HCHs) and Hexachlorobenzene (HCB) in the Arctic atmosphere, Environ. Sci. Technol., 40, 6601-6607, 2006.

Sundquist, H., Berge, E., and Kristjansson, J. E.: Condensation and cloud parameterization studies with a mesoscale numerical prediction model, Mon. Weather Rev., 117, 1641-1657, 1989.

Tian, C., Ma, J., Liu, L., Jia, H., Xu, D., and Li, Y.: A modeling assessment of association between East Asian summer monsoon and fate/outflow of a-HCH in Northeast Asia, Atmos. Environ. 43, 3891-3901, 2009.

Toose, L., Woodfine, D. G., MacLeod, M., Mackay, D., and Gouin, J.: BETR-World: a geographically explicit model of chemical fate: application to transport of a-HCH to the Arctic, Environ. Pollut., 126, 223-240, 2004.

van Drooge, B. L., Grimalt, J. O., Camarero, L., Catalan, L., Stuchlik, E., and Carcia, C. T.: Atmospheric semivolatile organochlorine compounds in European high-mountain areas (central Pyrenees and high Tatras), Environ. Sci. Technol., 38, 3525-3532, 2004.

Wania, F. and Mackay, D.: Global fractionation and cold condensation of low volatility organochlorine compounds in polar regions, Ambio., 22, 10-18, 1993.

Wania, F. and Mackay, D.: Tracking the distribution of persistent organic pollutants, Environ. Sci. Technol., 30, A390-A396, 1996.

Wania, F., Hoff, J. T., Jia, C. Q., and Mackay, D.: The effects of snow and ice on the environmental behaviour of hydrophobic organic chemicals, Environ. Pollut., 102, 25-41, 1998.

Wania, F., Semkin, R., Hoff, J. Y., and Mackay, D.: Modelling the fate of non-polar organic chemicals during the melting of an Arctic snowpack, Hydrol. Proc., 13, 2245-2256, 1999.

Wania, F. and Westgate, J. N.: On the mechanism of mountain coldtrapping of organic chemicals, Environ. Sci. Technol., 42, 9092 9098, 2008.

Xiao, H., Li, N., and Wania, F.: Compilation, evaluation, and selection of physical-chemical property data for $\alpha-, \beta-$, and $\beta$-Hexachlorocyclohexane, J. Chem. Eng. Data, 49, 173-185, 2004.

Zhang, L., Ma, J., Venkatesh, S., Li, Y.-F., and Cheung, P.: Modeling evidence of episodic intercontinental long-range transport of lindane, Environ. Sci. Technol., 42, 8791-8797, 2008.

Zhang, L., Ma, J., Tian, C., and Li, Y.: Atmospheric transport of persistent semi-volatile organic chemicals to the Arctic and cold condensation in the mid-troposphere - Part 2: 3-D modeling of episodic atmospheric transport, Atmos. Chem. Phys., 10, 73157324, doi:10.5194/acp-10-7315-2010, 2010. 